\title{
KARAKTERISASI SIFAT FISIK DAN KETAHANAN TERHADAP LINGKUNGAN ASAM LAHAN GAMBUT MATERIAL CANAL BLOCKING BERBASIS KOMPOSIT KARET ALAM
}

\author{
Physical Properties and Peat Lands Acid Resistance Characterization of Natural \\ Rubber Composite Based Canal Blocking
}

Norma Arisanti KINASIH*, Adi CIFRIADI dan Thomas WIJAYA

Pusat Penelitian Karet

Jalan Salak Nomor 1 Bogor 16151 Jawa Barat

*Email: norma.kinasih88@gmail.com

Diterima : 11 Februari 2018 / Disetujui : 31 Mei 2018

\begin{abstract}
The utilizing of natural rubber composite as an alternative canal blocking material structure is a novel tidings. The aims of this experiment was to reveal the physical and mechanical properties and peat lands acid resistance characterization of rubber composite. Natural rubber composite based canal blocking was designed with different hardness, i.e 70,80 and 90 Shore A. In addition, the type of the particulate was carbon black and calcium carbonate $\left(\mathrm{CaCO}_{3}\right)$. The obtained data showed that the optimum natural rubber composite used $140 \mathrm{phr}$ and $65 \mathrm{phr}$ (per hundred rubber) of $\mathrm{CaCO}_{3}$ and carbon black, respectively. This composite had good mechanical properties and acidic environment peatland resistancy on $\mathrm{pH} 3$ (equal to sulfuric acid 20\%) and pH 2,5 (equal to sulfuric acid 40\%), which was due to low swelling index and value change of mechanical properties after immersion in sulfuric acid $20 \%$ and $40 \%$.
\end{abstract}

Keywords: Canal blocking; mechanical properties; natural rubber composite; peat lands acid.

\begin{abstract}
Abstrak
Penggunaan komposit berbasis karet alam sebagai alternatif material konstruksi canal blocking merupakan hal yang baru. Tujuan penelitian adalah mempelajari sifat fisik dan mekanik dan ketahanan terhadap lingkungan asam lahan gambut material canal blocking yang terbuat dari komposit karet alam. Komposit karet alam didisain dengan nilai kekerasan yang divariasikan
\end{abstract}

sebesar 70, 80 dan 90 Shore A dan jenis bahan pengisi tipe partikulat meliputi karbon hitam dan kalsium karbonat $\left(\mathrm{CaCO}_{3}\right)$. Data hasil penelitian menunjukkan bahwa formulasi komposit karet alam untuk produksi canal blocking terbaik diperoleh menggunakan partikulat $\mathrm{CaCO}_{3}$ sebanyak 140 bsk dan karbon hitam 65 bsk. Komposit karet alam ini memiliki sifat fisik dan ketahanan yang baik pada lingkungan asam lahan gambut yang memiliki tingkat keasamaan $\mathrm{pH} 3$ (setara dengan larutan asam sulfat 20\%) dan $\mathrm{pH} 2,5$ (setara dengan larutan asam sulfat 40\%), yang ditandai dengan rendahnya perubahan volume dan sifat fisika serta mekanik vulkanisat setelah perendaman dalam larutan asam sulfat $20 \%$ dan $40 \%$.

Kata kunci: Asam lahan gambut; canal blocking; komposit karet alam; sifat fisik

\section{PENDAHULUAN}

Canal blocking adalah suatu bangunan pengatur tata kelola air pada lahan gambut untuk menurunkan permukaan air tanah. Pemanfaatan lahan gambut sebagai area budidaya tanaman pangan dan perkebunan membutuhkan lingkungan aerobik bagi perakaran tanaman, maka perlu dibuat kanal atau saluran air untuk menurunkan permukaan air tanah (Napitupulu \& Mudiantoro, 2015; Widyanti, 2011). Namun, saat ini terjadi pembuatan kanal yang tidak terkendali oleh masyarakat sehingga terjadi drainase air yang berlebihan dan menyebabkan penurunan air tanah secara drastis. 
Penurunan muka air tanah (water table) pada lahan yang didrainase dapat mengubah suasana anaerob (jenuh air) menjadi aerob (tidak jenuh air) sehingga meningkatkan laju dekomposisi dan emisi $\mathrm{CO}_{2}$. Dilaporkan bahwa emisi $\mathrm{CO}_{2}$ dari lahan gambut dan alih guna lahan hutan lebih dari $50 \%$ dari total emisi Indonesia (Boer et al., 2009; Hooijer et al., 2010). Selain itu, lahan gambut menjadi rawan terhadap kebakaran dan saat terjadi kebakaran, api sulit dipadamkan karena air tanah sudah menurun jauh dari permukaan (Napitupulu $\&$ Mudiantoro, 2015).

Canal blocking yang digunakan saat ini belum sepenuhnya mempertimbangkan faktor pengaturan keluar dan masuknya air sehingga kedalaman air tanah tidak dapat diatur sesuai dengan syarat tumbuh tanaman. Disain canal blocking yang baik seharusnya dapat mengalirkan kelebihan air saat musim hujan dan menahan air saat musim kemarau untuk mempertahankan lengas tanah. Selain itu, disain canal blocking belum mempertimbangkan aspek sifat material seperti kekuatan, keawetan dan kemudahan operasional. Sekarang ini, canal blocking dibuat secara tradisional dengan disain sederhana dari bahan yang ada di kawasan tersebut (Ritzema, Limin, Kusin, Jaunianen, \& Wosten, 2014), seperti kayu, papan kayu, karung pasir, pipa paralon dan kain terpal, dimana bahanbahan tersebut memiliki kekuatan yang sedang dan keawetan yang rendah. Maka, pada penelitian ini akan dikembangkan disain canal blocking yang mempertimbangkan faktor water level dan menggunakan material berbasis komposit karet alam, dimana memiliki kekuatan bahan yang kuat dibandingkan material pembangun canal blocking umumnya .

Komposit karet alam merupakan kombinasi dari material pengisi (filler) yang berfungsi sebagai penguat, baik dalam bentuk serat ataupun partikulat dan kompon karet (elastomer) yang berfungsi sebagai matrik (Vinson \& Sierakowski, 1993). Secara garis besar, bahan komposit terdiri dari tiga macam, yaitu komposit partikel, komposit serat dan komposit laminat (Cifriadi, 2010). Pada penelitian ini akan dikembangkan material komposit karet alam dengan penguat jenis partikulat sebagai bahan baku pembuatan canal blocking. Penambahan partikulat dimaksudkan untuk meningkatkan kekuatan material dan menurunkan biaya produksi canal blocking. Terdapat dua jenis partikulat yang digunakan yaitu partikulat berpenguat berupa karbon hitam dan partikulat tidak berpenguat seperti $\mathrm{CaCO}_{3}$. Karakterisasi sifat fisik komposit tersebut akan dianalisis untuk mengetahui kekuatan struktur material sebagai bahan baku canal blocking.

Ketahanan karet alam pada lingkungan asam sangat bergantung pada konsentrasi asam tersebut (Long, 1985). Hasil analisis Akhtar, Setua, De dan De (1985) menunjukkan bahwa karet alam yang divulkanisasi dengan sulfur dan tanpa bahan pengisi terdegradasi sempurna pada lingkungan asam (asam nitrat $70 \%$ ) selama 2 jam perendaman. Ketahanan komposit karet alam untuk canal blocking pada lingkungan asam lahan gambut perlu dianalisis, mengingat mineral dasar di bawah tanah gambut umumnya berupa sulfat, yang memiliki $\mathrm{pH}$ yang rendah (Kselik et al., 1993). Maka, pada penelitian kali ini akan dianalisis pula ketahanan komposit karet alam terhadap lingkungan asam lahan gambut.

\section{BAHAN DAN METODE}

Pelaksanaan penelitian dilakukan di Pabrik Percobaan dan Laboratorium Penguji Pusat Penelitian Karet pada bulan Maret hingga Desember 2016. Bahan baku karet alam tipe SIR 20 diperoleh dari UD Sukses Jaya Makmur. Sedangkan bahan kimia komposit karet seperti karbon hitam (CB N330) diproduksi oleh Cabot, sulfur, minarex oil, $\mathrm{CaCO}_{3}$, cumarrone resin, MBTS, DPG, Antilux, TMQ, $\mathrm{ZnO}$ dan asam stearat berasal dari supplier lokal. Reagen asam sulfat $\left(\mathrm{H}_{2} \mathrm{SO}_{4} 97 \%\right)$ berspesifikasi pure analysis dari Merck. Peralatan dan instrument yang digunakan antara lain: mesin giling terbuka (open mill-Berstorf), Moving Die Rheometer (MDR), compression molding, cetakan canal blocking, hardness tester, Lloyd Tensometer dan $\mathrm{pH}$ meter (Metrohm).

\section{Formulasi Canal Blocking Berbasis Komposit Karet Alam}

Canal blocking harus memiliki kekuatan yang cukup agar dapat diaplikasikan di lapangan sehingga mampu menahan kekuatan laju air di lahan gambut. 
Material pembangun canal blocking berbasis komposit karet alam dikondisikan agar mampu memenuhi sifat tersebut, dengan pengaturan utama terhadap kekerasan (hardness) yang tinggi, kekakuan (stiffness) yang tinggi, dan kekuatan. Bahan yang diperlukan untuk mendapatkan sifat tersebut adalah dengan menambahkan bahan penguat atau pengisi dalam kompon karet yang berbentuk partikulat, seperti filler carbon black dan $\mathrm{CaCO}_{3}$. Kompon karet alam diformulasikan untuk mendapatkan kekerasan yang bervariasi dari nilai kekerasan sebesar 70, 80, dan 90 shore A. Kompon dengan kekerasan 90 Shore A selanjutnya juga divariasikan bahan pengisinya, tanpa dan dengan mengkombinasikan karbon hitam (carbon black) dan kalsium karbonat $\left(\mathrm{CaCO}_{3}\right)$. Kombinasi bahan pengisi carbon black dengan $\mathrm{CaCO}_{3}$ diharapkan dapat meminimalisir biaya bahan tanpa menurunkan sifat mekanis. Keempat formula tersebut selanjutnya diberi kode S70, S80, S90 dan S91. Adapun keempat formula tersebut disajikan pada Tabel 1 .

Bahan-bahan pada Tabel 1 tersebut selanjutnya digiling bertahap menggunakan mesin giling terbuka (open mill-Berstorf). Sebelum dicampur dengan bahan-bahan kimia, karet alam SIR 20 terlebih dahulu dimastikasi selama 2 menit. Selama mastikasi tersebut, dimasukkan pula resin hingga resin melunak dan bercampur dengan karet selama 6-7 menit. Bahan selanjutnya yang dimasukkan adalah asam stearat dan $\mathrm{ZnO}$. Kedua bahan tersebut digiling hingga bercampur, kurang lebih 1 menit. Selanjutnya digiling Antilux dan TMQ selama 1 menit. CB N330 atau $\mathrm{CaCO}_{3}$ digiling bersamaan dengan Minarex Oil, untuk mempermudah penghomogenan bahan pengisi partikulat pada matrik karet. Kedua bahan tersebut digiling kurang lebih selama 5 menit. Bahan selanjutnya yaitu DPG, MBTS dan Sulfur secara bertahap selama 1 menit. Bahan-bahan yang telah bercampur tersebut selanjutnya dihomogenkan kembali selama 1 menit. Kompon yang telah homogen selanjutnya ditipiskan hingga ketebalannya $3 \mathrm{~mm}$. Kompon yang diperoleh selanjutnya disimpan pada suhu ruang selama 24 jam sebelum divulkanisasi. Waktu kematangan optimum vulkanisat ditentukan berdasarkan hasil pengujian karakteristik vulkanisasi menggunakan instrument Moving Die Rheometer (MDR). Kompon selanjutnya divulkanisasi menggunakan compression molding pada suhu $150^{\circ} \mathrm{C}$ dan tekanan $100 \mathrm{Kg} / \mathrm{cm}^{2}$ selama waktu kematangan optimum yang diperoleh dari uji karakteristik vulkanisasi.

\section{Uji Karakterisasi Pematangan Kompon Komposit Karet Alam}

Masing-masing kompon tersebut diuji pada suhu $150^{\circ} \mathrm{C}$. Pengujian dengan rheometer tersebut menyajikan parameter karakteristik pematangan yang meliputi; torsi maksimum $\left(M_{\mathrm{H}}\right)$ dan minimum $\left(M_{\mathrm{L}}\right)$, delta torsi $\left(M_{\mathrm{H}}-M_{\mathrm{L}}\right)$, waktu optimum

Tabel 1. Formula komposit karet alam

Table 1. The formulation of natural rubber composite

\begin{tabular}{lcccc}
\hline \multirow{2}{*}{$\begin{array}{c}\text { Bahan } \\
\text { Materials }\end{array}$} & \multicolumn{4}{c}{ Formula kompon karet (bsk) } \\
& St0 & $\mathrm{S} 80$ & $\mathrm{~S} 90$ & $\mathrm{~S} 91$ \\
\cline { 2 - 5 } & 100 & 100 & 100 & 100 \\
SIR 20 & 65 & 85 & 105 & 65 \\
Karbon hitam (CB N330) & 5 & 5 & 5 & 5 \\
Minarex oil & - & - & - & 140 \\
CaCO3 & 3 & 3 & 3 & 3 \\
Cumarrone resin & 2,4 & 2,4 & 2,4 & 2,4 \\
Sulfur & 1,6 & 1,6 & 1,6 & 1,6 \\
MBTS & 0,2 & 0,2 & 0,2 & 0,2 \\
DPG & 3 & 3 & 3 & 3 \\
Antilux & 3 & 3 & 3 & 3 \\
TMQ & 5 & 5 & 5 & 5 \\
ZnO & 1 & 1 & 1 & 1 \\
Asam stearat & & & & \\
\hline
\end{tabular}


vulkanisasi $\left(t_{g_{0}}\right)$, waktu scorch vulkanisasi $\left(\mathrm{t}_{\mathrm{s} 2}\right)$ dan indeks kecepatan reaksi (Cure Rate Index/CRI). CRI dihitung berdasarkan perbedaan $t_{90}$ dan $t_{\mathrm{s} 2}$ dengan persamaan berikut (Chonkaew et al., 2010).

$$
\mathrm{CRI}=\frac{100}{\mathrm{t}_{90}-\mathrm{t}_{\mathrm{s} 2}}
$$

\section{Uji Sifat Fisik Vulkanisat Canal Blocking Berbasis Komposit Karet Alam}

Pengujian sifat fisik vulkanisat karet canal blocking meliputi berat jenis, kekerasan, kuat tarik, perpanjangan putus, modulus $300 \%$, ketahanan sobek, kepegasan pantul dan tekanan menyeluruh. Pengujian berat jenis mengacu pada ISO 2781:2008. Pengujian kekerasan vulkanisat sesuai dengan ASTM D.2240-05, dengan sampel uji berupa tiga lapis lembaran persegi $(15 \times 15 \mathrm{~cm})$ setebal $2 \mathrm{~mm}$. Pengujian kuat tarik, perpanjangan putus dan modulus 300\% sesuai dengan ASTM D.41206AE2, dengan sampel uji berbentuk dumbbell tipe 2. Pengujian dilakukan menggunakan Llyod Tensometer pada suhu ruang. Pengujian ketahanan sobek mengacu pada ISO 34(2):2011. Pengujian tekanan menyeluruh sesuai dengan ASTM D575-07. Pengujian kepegasan pantul sesuai dengan ASTM D1054-02.

Perubahan Volume $(\%)=\frac{W s-W u}{W u} \times 100 \%$

\section{Uji Ketahanan Vulkanisat Canal Blocking Berbasis Komposit Karet Alam terhadap Lingkungan Asam}

Pengujian ketahanan vulkanisat terhadap lingkungan asam dilakukan dengan merendam vulkanisat pada asam sulfat $\mathrm{pH}$ 2,5 dan 3. Pengujian dilakukan sesuai ASTM D471-06E1. Perendaman dilakukan pada suhu ruang (RT) dan $70^{\circ} \mathrm{C}$ selama 72 jam. Perendaman pada suhu $70^{\circ} \mathrm{C}$ untuk mengetahui pengaruh accelerated thermal ageing (pengusangan panas dipercepat) pada ketahanan vulkanisat (Gu \& Itoh, 2011). Persen perubahan volume karet dihitung berdasarkan persamaan (2) ini, dengan Wu adalah volume awal sebelum perendaman dan Ws adalah volume setelah perendaman.

\section{Uji Ketahanan Ozon Vulkanisat Canal Blocking Berbasis Komposit Karet Alam}

Pengujian ketahanan vulkanisat terhadap ozon dilakukan dengan memaparkan vulkanisat dengan ozon pada konsentrasi 25 pphm selama 48 jam dalam ozone aging tester. Pengujian dilakukan sesuai ASTM D1149-07(ra 2012). Ketahanan vulkanisat terhadap ozon diketahui melalui pengamatan terhadap timbulnya retakan (cracking) pada permukaan vulkanisat setelah dipapari ozon pada kondisi pengujian.

\section{Uji Karakteristik Morfologi Vulkanisat Canal Blocking Berbasis Komposit Karet Alam}

Pengujian karakteristik morfologi vulkanisat dilakukan untuk mengetahui penampakan morfologi karet yang telah direndam pada lingkungan asam. Sampel uji yang digunakan adalah sampel vulkanisat yang memiliki ketahanan yang terbaik pada lingkungan asam ekstrim (asam sulfat ber $\mathrm{pH} 2,5)$ dan telah dirusak dengan menggunakan tensometer. Sebagai kontrol digunakan pula vulkanisat dari kompon terbaik sebelum mengalami perendaman pada lingkungan asam ekstrim. Pengujian karakteristik morfologi vulkanisat menggunakan Scanning Electron Miscroscopy (SEM) ZEISS Instrument pada akselerasi voltase $16 \mathrm{kV}$. Permukaan sampel yang rusak karena tarikan dilapisi dengan emas untuk menjaga agar tidak terjadi pengaruh elektrostatik selama pengamatan. Pengamatan morfologi vulkanisat dilakukan pada perbesaran 2000 dan 10.000 kali.

\section{HASIL DAN PEMBAHASAN}

\section{Karakteristik Pematangan Kompon Canal Blocking Berbasis Komposit Karet Alam}

Hasil karakteristik pematangan keempat kompon tersebut disajikan pada Tabel 2. Hasil karakteristik pematangan menunjukkan bahwa S90 memiliki torsi maksimum, torsi minimum dan delta torsi tertinggi. Gonza'lez, Rodriguez, Del Campo, dan Marcos-Fernandez (2005) menyatakan bahwa nilai torsi maksimum dan delta torsi menunjukkan ikatan silang yang terbentuk dari sebuah kompon. Hasil tersebut 
menunjukkan bahwa penambahan bahan pengisi meningkatkan ikatan silang yang terbentuk. Sedangkan torsi minimum $\left(M_{\mathrm{L}}\right)$ merupakan indikator viskositas kompon (Konar \& Saha, 2012; Marković et al., 2013; Indra et al., 2013) serta memberikan informasi terkait kemampuan proses dari kompon (Nabil, Ismail \& Azura, 2013). Semakin tinggi viskositas suatu kompon maka akan semakin sulit proses pengomponan kompon tersebut. Hal ini disebabkan karena umumnya karbon hitam terbentuk dari pembakaran minyak bumi, yang terdiri dari percabangan agregat yang tidak reguler. Penyebaran karbon hitam pada jaringan karet dilakukan dengan sendirinya. Dengan meningkatnya kandungan karbon hitam, rantai ikatan semakin pendek dan jumlah ikatan diantara dua ikatan silang akan berkurang (Heinrich \& Vilgis, 1993). Maka, semakin banyak karbon hitam yang dimasukkan, semakin sulit proses pengomponan berlangsung.

Pada Tabel 2 diketahui bahwa kompon S91 memiliki torsi maksimum, minimum dan delta torsi yang lebih kecil dibandingkan s90. Hasil tersebut menunjukkan bahwa interaksi antar permukaan molekul karet dan bahan pengisi (rubber bound) pada kompon formula S91 lebih rendah dibandingkan dengan kompon formula S90. Hal ini dikarenakan pada kompon formula S91 memiliki banyak kandungan bahan pengisi $\mathrm{CaCO}_{3}$ yang bersifat bukan penguat. Hal ini dapat pula karena jumlah bahan pengisi yang ditambahkan telah melebihi batasnya, sehingga tidak bekerja maksimal (Azura, Ghazali, \& Mariatti, 2008).
Hasil pengamatan waktu optimum $\left(t_{90}\right)$, scorch time $\left(t_{s 2}\right)$ dan indeks kecepatan reaksi (CRI) vulkanisasi kompon canal blocking menunjukkan karakteristik kompon selama pemasakan dan sifat-sifat ini sangat penting selama pemrosesan pembuatan produk karet. Tabel 2 menunjukkan bahwa penambahan dosis karbon hitam mempercepat waktu vulkanisasi, waktu scorch dan CRI. Hasil pengamatan ini sesuai dengan penelitian Saad et al. (2009) dan Ismail et al. (2011), dimana semakin banyak bahan pengisi yang dimasukkan maka semakin singkat $t_{90}$ dan $t_{s 2}$.

\section{Sifat Fisik Vulkanisat Canal Blocking Berbasis Komposit Karet Alam}

Sifat fisik vulkanisat canal blocking disajikan pada Tabel 3. Berdasarkan hasil pengamatan diketahui bahwa keempat kompon memiliki berat jenis yang meningkat seiring penambahan karbon hitam. Penambahan dosis karbon hitam menambah massa dari kompon, sehingga berat jenis vulkanisat mengalami kenaikan. Berat jenis tertinggi tampak pada kompon S91, yang diberi dosis $140 \mathrm{phr} \mathrm{CaCO}_{3}$.

Kekerasan vulkanisat canal blocking juga mengalami kenaikan seiring penambahan dosis karbon hitam (Saad et al., 2009). Perhitungan kekerasan vulkanisat karet dapat diprediksi dari nilai kekerasannya secara teoritis. Karet alam secara teoritis memiliki kekerasan sebesar 40 Shore A. Penambahan bahan pengisi dan pelunak pada karet akan mempengaruhi kekerasan karet tersebut. Bahan pengisi peguat seperti karbon hitam, akan

Tabel 2. Karakteristik pematangan kompon canal blocking berbasis komposit karet alam Table 2. Curing characteristic of natural rubber composite based canal blocking compound

\begin{tabular}{|c|c|c|c|c|}
\hline \multirow[t]{2}{*}{$\begin{array}{c}\text { Karakteristik pematangan } \\
\text { Curing characteristic }\end{array}$} & \multicolumn{4}{|c|}{$\begin{array}{l}\text { Kompon canal blocking berbasis komposit karet alam } \\
\text { Natural rubber composite based canal blocking } \\
\text { compound }\end{array}$} \\
\hline & $\mathrm{S} 70$ & $\mathrm{~S} 80$ & S90 & S91 \\
\hline $\mathrm{M}_{\mathrm{H}}(\mathrm{kg}-\mathrm{cm})$ & 12,45 & 21,05 & 27,73 & 17,71 \\
\hline $\mathrm{M}_{\mathrm{L}}(\mathrm{kg}-\mathrm{cm})$ & 11,45 & 17,25 & 23,46 & 16,44 \\
\hline $\mathrm{M}_{\mathrm{H}}-\mathrm{M}_{\mathrm{L}}(\mathrm{kg}-\mathrm{cm})$ & 1 & 3,8 & 4,27 & 1,27 \\
\hline$t_{90}$ (menit) & 6,06 & 6,05 & 5,54 & 5,18 \\
\hline $\mathrm{t}_{\mathrm{s} 2}$ (menit) & 2,01 & 1,37 & 0,05 & 1,39 \\
\hline CRI & 24,69 & 21,37 & 18,21 & 26,38 \\
\hline
\end{tabular}


Tabel 3. Sifat fisik dan mekanik vulkanisat canal blocking berbasis komposit karet alam Table 3. Physical and mechanical properties of natural rubber composite based canal blocking vulcanizate

\begin{tabular}{|c|c|c|c|c|}
\hline \multirow{2}{*}{$\begin{array}{l}\text { Sifat fisika dan mekanik } \\
\text { Physical and mechanical properties }\end{array}$} & \multicolumn{4}{|c|}{$\begin{array}{l}\text { Vulkanisat canal blocking berbasis komposit karet alam } \\
\text { Natural rubber composite based canal blocking vulcanizate }\end{array}$} \\
\hline & S70 & $\mathrm{S} 80$ & S90 & S91 \\
\hline Berat jenis $\left(\mathrm{g} / \mathrm{cm}^{3}\right)$ & 1,161 & 1,208 & 1,236 & 1,547 \\
\hline Kekerasan (Shore A) & 75 & 84 & 87 & 82 \\
\hline Kuat tarik $\left(\mathrm{N} / \mathrm{mm}^{2}\right)$ & 21,2 & 17,1 & 12,25 & 9,8 \\
\hline perpanjangan putus (\%) & 460 & 270 & 170 & 295 \\
\hline modulus $300 \%(\mathrm{~N} / \mathrm{mm})$ & 14,4 & - & - & - \\
\hline Ketahanan sobek (N/mm) & 91,55 & 40,05 & 36,35 & 27,95 \\
\hline kepegasan pantul (\%) & 40 & 32 & 30 & 35 \\
\hline Tekanan menyeluruh $100 \%\left(\mathrm{kN} / \mathrm{m}^{2}\right)$ & 20,35 & 19,18 & 23,38 & 23,55 \\
\hline
\end{tabular}

meningkatkan kekerasan $1 / 2$ dari jumlah yang ditambahkan. Penambahan bahan pengisi bukan penguat seperti $\mathrm{CaCO}_{3}$, akan meningkatkan kekerasan $1 / 7$ dari jumlah yang ditambahkan. Sedangkan, penambahan pelunak dapat menurunkan kekerasan $1 / 2$ dari jumlah yang ditambahkan.

Pada kompon S70 dan S80 nilai kekerasan yang diperoleh di atas dari perkiraan kekerasan secara teoritis, sedangkan S90 dan S91 nilai kekerasan yang diperoleh di bawah perkiraan kekerasan secara teoritis. Kekerasan kompon S91 memiliki kekerasan yang lebih kecil dibandingkan S90. Hal ini dimungkinkan karena kompon S91 diberi pengisi $\mathrm{CaCO}_{3}$ yang merupakan bahan pengisi bukan penguat, sehingga memiliki efek kekerasan yang lebih rendah dibandingkan karbon hitam.

Karet alam dengan kekerasan yang besar menunjukkan bahwa karet memiliki kekakuan (stiffness) yang tinggi atau tidak elastis sehingga cenderung memiliki nilai kuat tarik, perpanjangan putus, modulus $300 \%$, ketahanan sobek dan kepegasan pantul yang rendah. Penambahan karbon hitam pada matriks karet menyebabkan dispersi pengisi dan interaksi antara pengisi dan matriks (Azura et al., 2008). Dengan semakin banyaknya pengisi yang ditambahkan maka interaksi pengisi dan matrik akan semakin lemah, sehingga menurunkan kekuatan karet (Job et al., 2003; Frohlich et al, 2005). Tabel 3 menunjukkan bahwa penambahan karbon hitam pada kompon cenderung menurunkan sifat kuat tarik, perpanjangan putus, modulus 300\%, ketahanan sobek dan kepegasan pantul vulkanisat canal blocking.

Nilai tekanan menyeluruh (compressive strength) menunjukkan kekuatan suatu vulkanisat. Pada kondisi lapangan di lahan gambut, terkadang debit air mengalami peningkatan saat pasang. Pengujian sifat fisika ini perlu dilakukan untuk mengetahui kekuatan kompon karet saat dihadapkan pada kondisi ekstrim di lapangan. Tabel 3 menunjukkan bahwa nilai tekanan menyeluruh pada vulkanisat meningkat seiring jumlah karbon hitam yang ditambahkan, nilai ini sejalan dengan kekerasan vulkanisat. Namun, nilai tekanan menyeluruh mengalami sedikit penurunan pada S80 dan kemudian naik kembali pada vulkanisat S90. Penurunan tersebut dimungkinkan karena matriks komposit (karet) mengalami kerusakan saat diberikan perlakukaan pengujian, sehingga nilai tekanan menyeluruhnya menurun.

\section{Ketahanan Asam Vulkanisat Canal Blocking Berbasis Komposit Karet Alam}

Lahan gambut umumnya bersifat asam. Mineral dasar di bawah tanah gambut umumnya berupa sulfat, yang memiliki $\mathrm{pH}$ yang rendah (Kselik et al., 1993). Sulistiyanto, Vasander, Jauhiainen, Rieley, dan Limin (2008) mensampling air pada kanal air di lahan gambut Kalimantan dan diketahui bahwa air tersebut memiliki $\mathrm{pH}$ diantara 3,32 dan 4,22. Maka pada pengujian ketahanan vulkanisat terhadap asam dilakukan simulasi pengujian dengan menggunakan asam sulfat $\left(\mathrm{H}_{2} \mathrm{SO}_{4}\right)$ yang memiliki pH sekitar 3 sebagai pengganti air lahan gambut. Untuk menghasilkan 
vulkanisat yang memiliki ketahanan asam yang tinggi, maka vulkanisat juga direndam pada asam sulfat ber-pH 2,5. Asam sulfat yang memiliki pH 2,5 dan 3 didekati dengan melakukan penelitian pendahuluan, membuat asam sulfat dengan beberapa konsentrasi lalu menguji $\mathrm{pH}$ asam sulfat tersebut. Hasil penelitian pendahuluan tersebut disajikan pada Tabel 4. Berdasarkan hasil penelitian pendahuluan diketahui bahwa asam sulfat ber-pH 2,5 dan 3 adalah asam sulfat dengan konsentrasi $40 \%$ dan $20 \%$.

Persen perubahan volume vulkanisat pada asam sulfat ber-pH 2,5 dan 3 disajikan pada Tabel 5. Pada suatu vulkanisat karet, ketahanannya tampak pada seberapa banyak vulkanisat tersebut terlarut pada larutan, yang ditandai dari mengembangnya vulkanisat dalam larutan (Lawandy et al., 1993; Ramesan et al., 2005; Mathew et al., 2006). Van Duin dan Dikland (2007) menjelaskan lebih lanjut bahwa tahan terhadap larutan merupakan suatu bentuk perlawanan vulkanisat untuk tidak mengembang di dalam larutan tersebut. Ketahanan ditentukan dari usaha vulkanisat untuk menahan agar tidak larut dalam bobot molekular terendah larutan dan dorongan elastis yang dapat meningkatkan penyerapan larutan. Maka, semakin sedikit volume pengembangannya, semakin tahan vulkanisat terhadap larutan.

Ketahanan vulkanisat pada kondisi asam pH 3 menunjukkan bahwa vulkanisat S80 memiliki pengembangan volume yang paling kecil dibanding vulkanisat lain pada suhu ruang. Pada umumnya, semakin banyak jumlah ikatan silang yang terbentuk maka semakin tahan vulkanisat terhadap larutan (Acharya et al, 2008; Manoj et al,
2011; Ismail et al., 2011). Namun, pada penelitian ini menunjukkan bahwa ikatan silang yang terbentuk tidak mempengaruhi ketahanan vulkanisat pada larutan asam. Vulkanisat S80 memiliki ikatan silang yang sedikit lebih kecil dibandingkan S90 (Tabel 3), namun memiliki kekuatan untuk menahan yang lebih besar. Pada hasil pengamatan SEM, Azura et al (2008) menunjukkan bahwa interaksi pengisipengisi lebih besar dibanding interaksi pengisi-matrik. Interaksi pengisi-pengisi yang lebih besar menyebabkan aglomerasi, sehingga ikatannya lebih mudah putus (Frohlich et al, 2005). Ikatan yang mudah putus inilah yang membuat larutan semakin mudah terserap masuk ke dalam komposit karet.

Pada pengujian ketahanan asam yang dipercepat (suhu $70^{\circ} \mathrm{C}$ ), ketahanan karet pada asam dengan $\mathrm{pH} 3$ menunjukkan bahwa volume pengembangan vulkanisat karet S70 hingga S90 setelah pengujian mengalami penurunan. Hasil ini menunjukkan bahwa ikatan silang karet tidak lagi mampu menahan laju masuknya larutan, sehingga karet larut dalam larutan asam. Sedangkan vulkanisat S91 menunjukkan volume pengembangan yang lebih besar setelah pengujian, maka representasi perubahan volumenya masih positif. Hasil ini menunjukkan bahwa pada pengujian dipercepat, vulkanisat S91 memiliki ketahanan asam $\mathrm{pH} 3$ dan suhu tinggi yang lebih baik dibanding vulkanisat lain. Kondisi ini dimungkinkan karena terbentuknya ikatan antara pengisi karbon hitam-karet-CaCO $\mathrm{CO}_{3}$ pada matriks komposit, sehingga ikatan yang terbentuk lebih kuat dan mampu menahan laju pengembangan volumenya pada suhu tinggi.

Tabel 4. pH asam sulfat pada berbagai konsentrasi Table 4. pH of sulfuric acid in various concentrations

\begin{tabular}{cc}
\hline $\begin{array}{c}\text { Konsentrasi } \mathrm{H}_{2} \mathrm{SO}_{4} \\
\text { Concentration of } \mathrm{H}_{2} \mathrm{SO}_{4} \\
(\%)\end{array}$ & $\mathrm{pH}$ \\
\hline 10 & 3,145 \\
20 & 3 \\
30 & 2,795 \\
40 & 2,45 \\
45 & 2,12 \\
50 & 2,025 \\
\hline
\end{tabular}


Tabel 5. Ketahanan vulkanisat canal blocking terhadap asam pH 2,5 dan 3 Table 5. Canal blocking vulcanizate resistance on $\mathrm{pH} 2.5$ and 3

\begin{tabular}{cccccc}
\hline $\begin{array}{c}\text { Kondisi pengujian } \\
\text { Treatment condition }\end{array}$ & \multicolumn{4}{c}{$\begin{array}{c}\text { Perubahan volume } \\
\text { Swelling behavior } \\
\text { (\%) }\end{array}$} \\
suhu & $\mathrm{pH}$ & $\mathrm{S} 70$ & $\mathrm{~S} 80$ & $\mathrm{~S} 90$ & $\mathrm{~S} 91$ \\
$\mathrm{RT}$ & 3 & 0,16 & 0,01 & 0,09 & 0,03 \\
$70^{\circ} \mathrm{C}$ & & $-0,40$ & $-0,21$ & $-0,12$ & 0,08 \\
$\mathrm{RT}$ & & $-0,12$ & $-0,20$ & 0,07 & 0,38 \\
$70^{\circ} \mathrm{C}$ & 2,5 & $-0,24$ & $-0,19$ & $-0,19$ & 0,51 \\
\hline
\end{tabular}

Ketahanan vulkanisat pada $\mathrm{pH}$ yang lebih asam $(\mathrm{pH} 2,5)$ menunjukkan bahwa hanya vulkanisat S90 dan S91 yang masih memiliki kekuatan untuk menghalangi masuknya larutan asam ke dalam karet. Vulkanisat S90 memiliki perubahan volume yang lebih kecil dibandingkan S91. Namun pada pengujian dipercepat (suhu $70^{\circ} \mathrm{C}$ ), vulkanisat S90 tidak lagi memiliki kekuatan untuk menahan masuknya larutan asam ke dalam karet, sehingga karet terlarut dalam larutan asam. Dari hasil pengujian diketahui bahwa vulkanisat S91 memiliki ketahanan asam $\mathrm{pH} 3$ dan 2,5 yang baik pada suhu ruang dan suhu $70^{\circ} \mathrm{C}$.

Ketahanan vulkanisat canal blocking terhadap asam diketahui pula dari kestabilan sifat mekanis vulkanisatnya setelah direndam pada asam sulfat $\mathrm{pH} 3$ dan 2,5 . Perubahan sifat mekanis vulkanisat karet setelah perendaman disajikan pada Gambar 1. Kekerasan pada masing-masing vulkanisat menunjukkan penurunan kekerasan setelah direndam pada larutan asam $\mathrm{pH} 3$ dan 2,5, namun penurunan kekerasan vulkanisat canal blocking tidak menunjukkan perubahan yang signifikan.

Kecenderungan yang hampir sama ditunjukkan pada sifat kuat tarik vulkanisat, dimana vulkanisat canal blocking menunjukkan penurunan setelah direndam pada $\mathrm{pH} 3$ dan 2,5. Pada vulkanisat $\mathrm{S} 70$ dan S80, vulkanisat menunjukkan penurunan sifat kuat tarik yang lebih besar setelah direndam di $\mathrm{pH}$ 2,5 dibandingkan $\mathrm{pH}$ 3. Hal ini menunjukkan bahwa vulkanisat S70 dan S80 hanya mampu bertahan ketika direndam hingga $\mathrm{pH}$ 3. Selain itu, nilai kuat tarik mengalami penurunan yang lebih besar saat diuji pada suhu $70^{\circ} \mathrm{C}$ dibanding di suhu ruang. Hasil ini menunjukkan bahwa vulkanisat S70 dan S80 tidak tahan terhadap perendaman dalam waktu yang relatif lama, dengan asumsi pengujian pada suhu $70^{\circ} \mathrm{C}$ merupakan pengujian yang dipercepat. Pada vulkanisat S90 dan S91 menunjukkan tren sebaliknya, dimana vulkanisat tersebut mengalami kenaikan nilai kuat tarik setelah direndam pada $\mathrm{pH}$ 2,5. Hasil ini menunjukkan bahwa vulkanisat S90 dan S91 mampu bertahan saat direndam pada $\mathrm{pH}$ hingga 2,5. Namun kenaikan tersebut hanya terjadi pada suhu pengujian di suhu ruang dan mengalami penurunan saat diuji pada suhu $70^{\circ} \mathrm{C}$. Hasil tersebut mengindikasikan bahwa vulkanisat S90 dan S91 mampu bertahan pada lingkungan asam ekstrim $(\mathrm{pH} 2,5)$ hanya pada kurun waktu yang singkat.

Penurunan kekerasan vulkanisat setelah perendaman menyebakan keelastisan karet meningkat sehingga nilai perpanjangan putus karet meningkat. Namun peningkatan perpanjangan putus karet hanya mampu meningkat saat diuji pada suhu ruang. Selanjutnya perpanjangan putus karet mengalami penurunan setelah diuji pada suhu $70^{\circ} \mathrm{C}$. Hasil ini menunjukkan bahwa vulkanisat karet hanya mampu bertahan di lingkungan asam ekstrim dalam kurun waktu yang singkat.

Berdasarkan serangkaian pengujian sifat mekanik vulkanisat tersebut diketahui bahwa kompon S90 dan S91 memiliki sifat mekanik yang lebih baik dibandingkan S70 dan S80, baik pada kondisi tanpa maupun dengan perendaman di lingkungan asam. Material pembangun canal blocking tidak hanya mempertimbangkan kualitas dan durabilitas bahan, namun juga nilai 

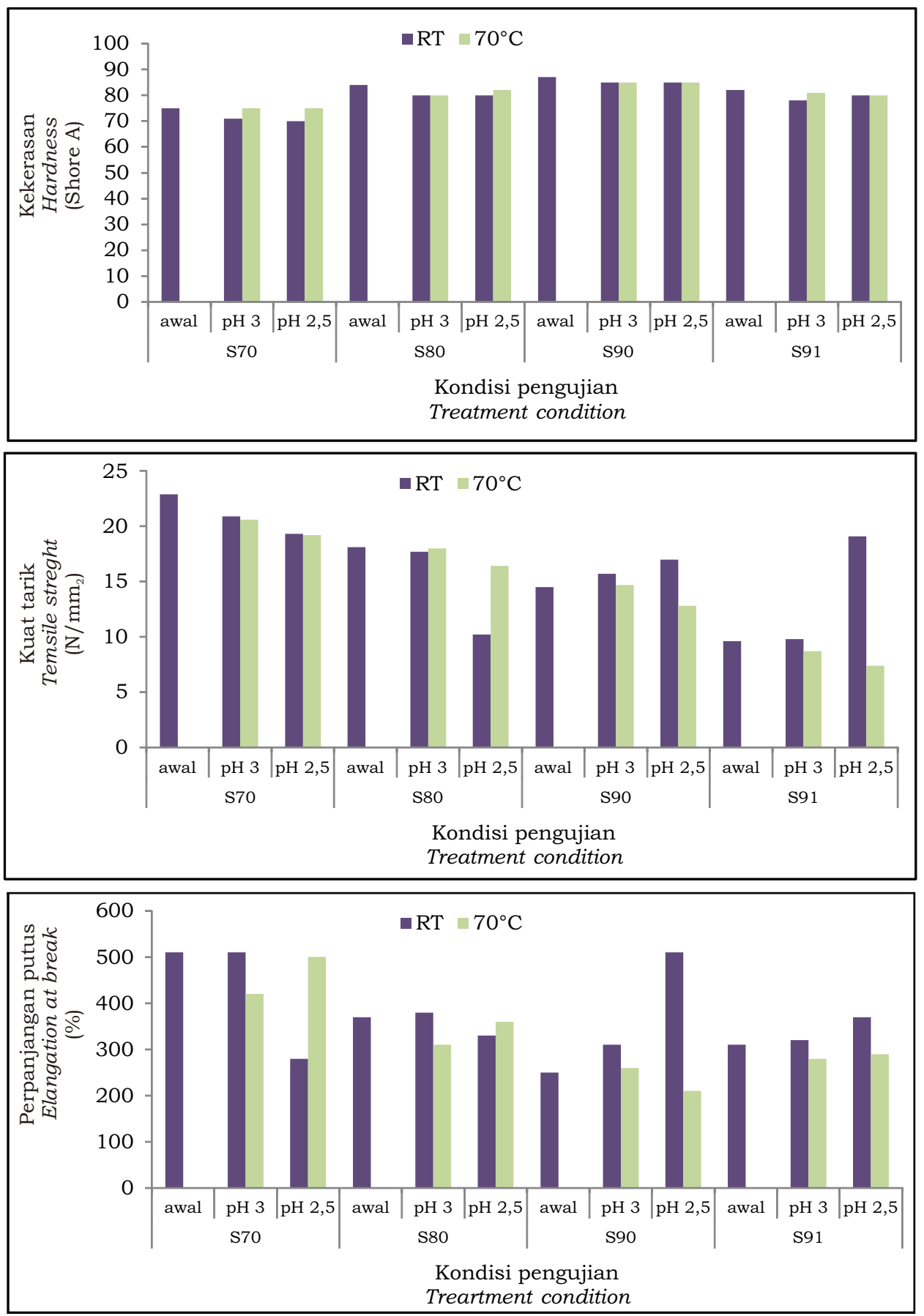

Gambar 1. Perubahan sifat mekanik vulkanisat canal blocking berbasis komposit karet alam setelah perendaman dalam lingkungan asam

Figure 1. Mechanical properties alteration of natural rubber based canal blocking vulcanizate after soaking in acid environment

ekonominya. Berdasarkan pertimbangan nilai ekonomis, kompon s90 yang bermaterial pengisinya berupa carbon black memiliki harga yang lebih tinggi dibandingkan $\mathrm{CaCO}_{3}$ pada kompon S91 sehingga kompon S91 yang dipilih untuk dikembangkan sebagai kompon penyusun material canal blocking berbasis karet alam. 


\section{Ketahanan Ozon Vulkanisat Canal Blocking Berbasis Komposit Karet Alam}

Aplikasi vulkanisat canal blocking berbasis karet alam di lapangan mengalami kontak dengan sinar matahari, seperti yang disajikan pada Gambar 2, sehingga vulkanisat tersebut harus memiliki ketahanan yang baik terhadap ozon. Pada hasil pengujian (Tabel 6) menunjukkan bahwa vulkanisat tidak mengalami keretakan setelah dipapar ozon 25 pphm selama 48 jam. Hasil ini menunjukkan bahwa vulkanisat tahan terhadap sinar matahari sehingga diharapkan dapat digunakan dengan baik di kondisi lapangan.

\section{Karakteristik Morfologi Vulkanisat Canal Blocking Berbasis Komposit Karet Alam}

Karakteristik morfologi vulkanisat canal blocking berbasis komposit karet alam disajikan pada Gambar 3. Pengujian karakteristik vulkanisat menggunakan kompon terpilih, yang tahan pada kondisi asam ekstrim yaitu S91. Pada pegamatan morfologi vulkanisat dengan perbesaran 2.000 kali (Gambar 3a dan 3b) tampak bagaimana interaksi dan pelekatan matriks karet dan pengisinya. Fu, Feng, Lauke dan Mai (2008) menyatakan bahwa kekuatan dan kekakuan komposit bergantung pada intekasi dan pelekatan matriks karet dan pengisinya. Pada gambar tersebut tampak bahwa interaksi matriks karet dan pengisinya telah homogen, namun pelekatannya belum optimal. Kondisi tersebut tampak lebih detail pada morfologinya dengan perbesaran 10.000 kali. Morfologi kompon S91 tersebut menyebabkan nilai kekuatan tariknya relatif kecil dibanding kompon lainnya (Tabel 3).

Pada perbesaran 10.000 kali tampak bahwa perendaman vulkanisat canal blocking pada asam sulfat ber $\mathrm{pH}$ 2,5 merubah morfologi vulkanisat. Pada Gambar 3c tampak pada ikatan matrik karet dan pengisinya terdapat celah yang kecil, namun pada Gambar 3d tampak celah yang lebih besar. Kondisi ini menunjukkan bahwa perendaman vulkanisat karet pada asam sulfat merenggangkan ikatan dan pelekatan matriks karet dan pengisi sehingga ikatan menjadi lemah dan menurunkan sifat fisik vulkanisat, seperti hasil pengujian sifat fisik setelah perendaman pada Gambar 1 .

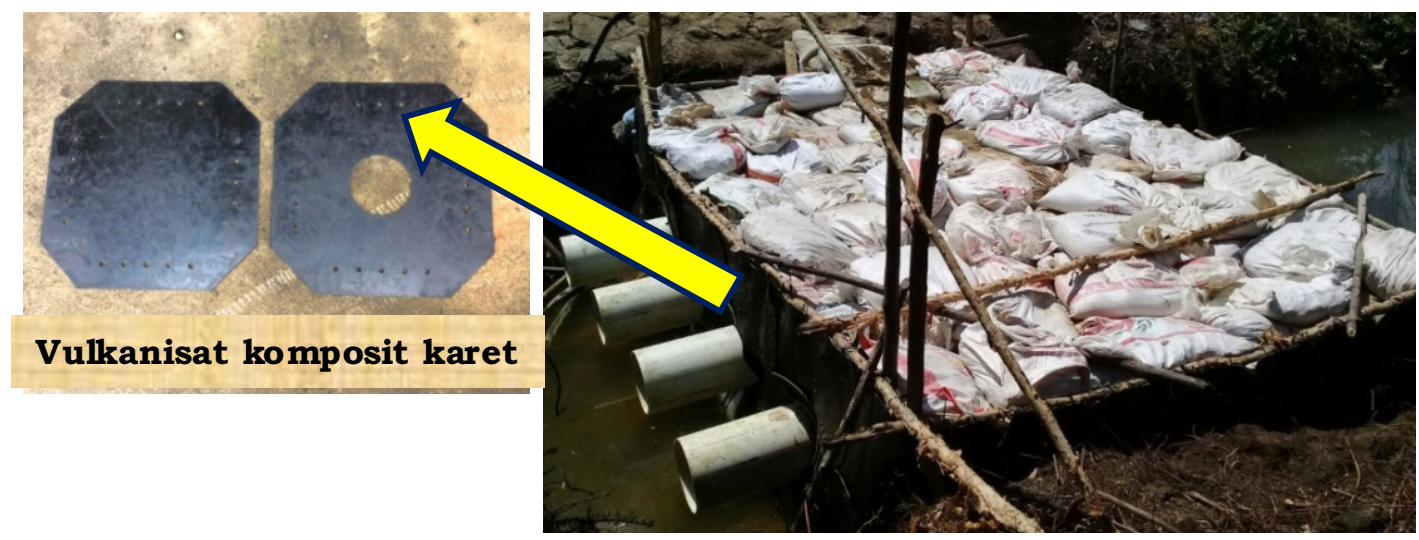

Gambar 2. Aplikasi vulkanisat komposit karet alam pada canal blocking Figure 2. Application of natural rubber composite on canal blocking

Tabel 6. Ketahanan vulkanisat canal blocking terhadap ozon

Table 6. Canal blocking vulcanizate resistance on ozone condition

\begin{tabular}{cc}
\hline Vulkanisat & $\begin{array}{c}\text { Penamapakan vulkanisat setalah uji ketahan ozon } \\
\text { Vulcanizate appearance after ozone aging test }\end{array}$ \\
\hline S70 & Tidak retak \\
S80 & Tidak retak \\
S90 & Tidak retak \\
S91 & Tidak retak \\
\hline
\end{tabular}




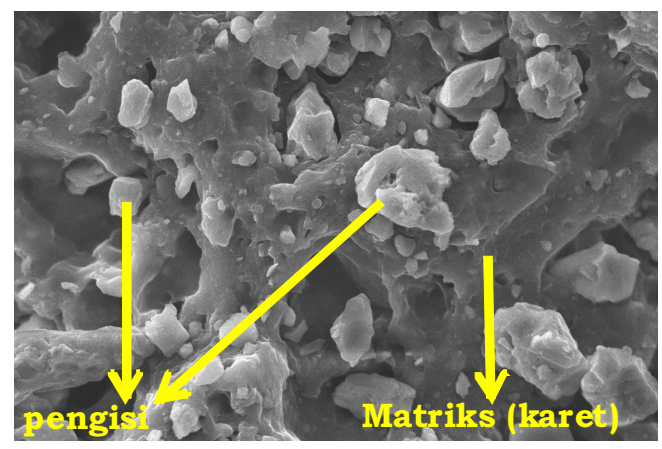

(a)

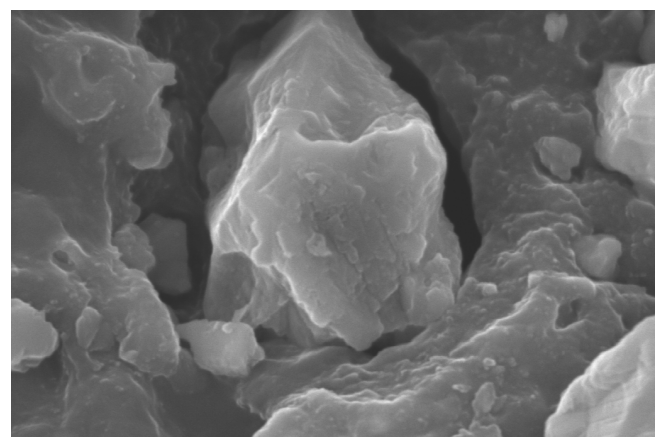

(c)

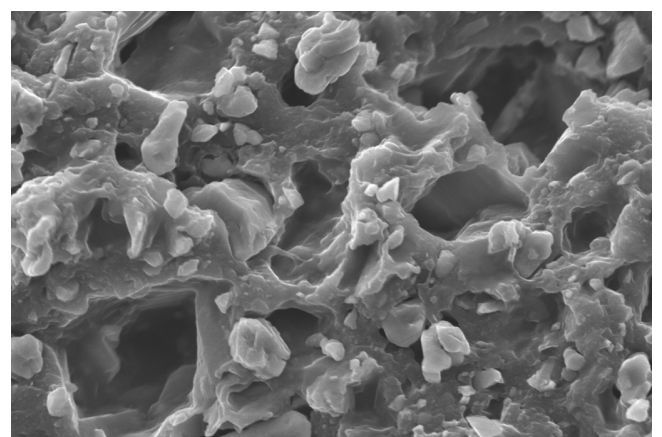

(b)

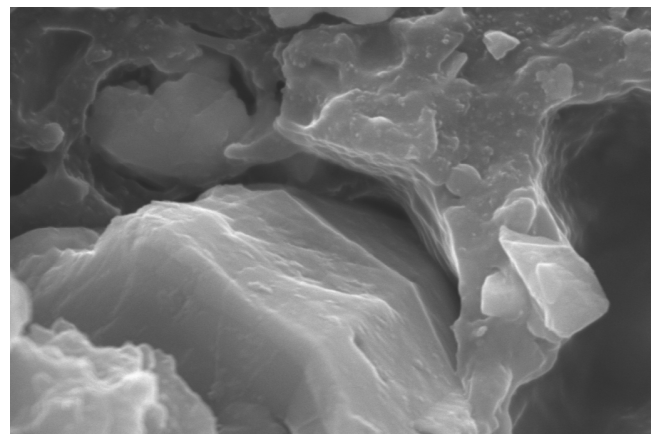

(d)

Gambar 3. SEM mikrograf vulkanisat canal blocking S91 (a) sebelum perendaman (perbesaran 2.000 kali) (b) setelah perendaman dalam asam sulfat ber-pH 2,5 dengan (perbesaran 2.000 kali) (c) sebelum perendaman dengan perbesaran 10.000 kali (d)setelah perendaman dalam asam sulfat ber-pH 2,5 (perbesaran 10.000 kali)

Figure 3. SEM micrograph of S91 canal blocking vulcanizate (a) before immersion (2000x magnification) (b) after immersion in suphate acid pH 2,5 (2000x magnification) (c) before immersion (10.000x magnification) (d) after immersion in suphate acid pH 2,5 (10.000x magnification)

\section{KESIMPULAN}

Formulasi komposit karet alam dengan partikulat telah dilakukan pada kegiatan penelitian ini. Formulasi komposit optimum adalah kompon S91 dengan partikulat komposit berupa $\mathrm{CaCO}_{3}$ sebanyak 140 phr. Komposit S91 memiliki sifat fisika dan ketahanan pada lingkungan asam lahan gambut yang baik. Selain itu, partikulat $\mathrm{CaCO}_{3}$ relatif lebih murah dibandingkan karbon hitam. Sehingga dapat meminimalisir biaya produksi canal blocking. Pengujian ketahanan vulkanisat pada asam dilakukan dengan merendam vulkanisat pada larutan asam sulfat $\mathrm{pH} 3$ dan 2,5, dimana kondisi tersebut equivalent dengan asam sulfat konsentrasi 20\% dan $40 \%$. Hasil pengujian ketahanan asam menunjukkan bahwa semakin banyak bahan partikulat yang ditambahkan maka semakin tahan vulkanisat terhadap lingkungan asam, dimana ditunjukkan dari kecilnya perubahan volume dan sifat fisik vulknisat setelah perendaman pada kompon S91.

\section{DAFTAR PUSTAKA}

Akhtar, S., Setua, D.K., De, P.P., \& De, S.K. (1985). Scanning electron microscopy studies on nitric acid corrosion of natural rubber vucanizates. Polymer Degradation and Stability, 10(4), 299317. Doi: 10.1016/0141-3910(85)900 97-7. 
Acharya, H., Kuila, T., Srivastava, S. K., \& Bhowmick, A.K. (2008). Effect of layered silicate on EPDM/EVA blend nanocomposite: Dynamic mechanical, thermal, and swelling properties. Polymer Composites, 29(4), 443-450. Doi: $10.1002 /$ pc.20433

Azura, A.R., Ghazali, S., \& Mariatti, M. (2008). Effects of the filler loading and aging time on the mechanical and electrical conductivity properties of carbon black filled natural rubber. Journal of Applied Polymer Science, $110(2), 747-752$. D o i : $10.1002 /$ app. 28517

Boer, R., Sulistyowati., Las, I., Zed, F., Masripatin, N., Kartakusuma, D.A., Hilman, D., \& Mulyanto, H.S. (2009). Summary for policy makers: Indonesia second national communication under the United Nations framework convention on climate change (UNFCCC). Jakarta, Indonesia: Ministry of Forestry

Chonkaew, W., Mingvanish, W., Kungliean, U., Rochanawipart, N., \& Brostow, W. (2010). Vulcanization characteristics and dynamic mechanical behavior of natural rubber reinforced with silane modified silica. Journal of Nanoscience and Nanotechnology, 11(3), 20182024. Doi: $10.1166 /$ jnn.2011.3563

Cifriadi, A. (2010). Material komposit dalam teknologi barang jadi karet. Warta Perkaretan, 29 (1), 64-71.

Frohlich, J., Niedermeier, W., \& Luginsland, H.D. (2005). The effect of filler-filler and filler-elastomer interaction on rubber reinforcement. Composite: Part A, 36, 449-460. Doi: 10.1016/j. compositesa.2004.10.004

Fu, S., Feng, X., Lauke, B., \& Mai, Y. (2008). Effects of particle size, particle/matrix interface adhesion and particle loading on mechanical properties of particulate-polymer composites. Composites: Part B, 39, 933-961. Doi: 10.1016/j.compositesb.2008.01.002
Gu, H., \& Itoh, Y. (2011). Aging behaviors of natural rubber in isolation bearings. Advanced Materials Research, 163$167,3343-3347$. D o i : 10.4028/www.scientific.net/AMR. 163 $-167.3343$.

Gonza`lez, L., Rodriguez, A., Del Campo, A., \& Marcos-Fernandez, A. (2002). Crosslink reaction of natural rubber with thiuram sulphur donors in the presence of a thiuram monosulfide. Journal of Applied Polymer Science, 85, 491-499. Doi: 10.1002/app.10438

Heinrich, G., \& Vilgis, T.A. (1993). Contribution of entanglements to the mechanical properties of carbon black filled polymer networks. Macromolecules, 26, 11090-1119. Doi: $10.1021 / \mathrm{ma} 00057 \mathrm{a} 035$

Hooijer, A., Page, S., Canadell, J.G., Silvius, M., Kwadijk, J., Wösten, H. \& Jauhiainen, J. (2010). Current and future $\mathrm{CO}_{2}$ emissions from drained peatlands in Southeast Asia. Biogeosciences, 7, 1505-1514. Doi: 10.5194/bg-7-1505-2010

Indra, S., Ismail, H., \& Azura, A.R. (2013). Alkaolamide as an accelerator, fllerdispersant and a plasticizer in silicaflled natural rubber compound. Polymer Testing, 32 (2), 1313-1321. Doi: $10.1016 / \mathrm{j}$.polymertesting. 2013.07.015

Ismail, H., Omar N.F., \& Othman, N. (2011). Effect of carbon black loading on curing characteristics and mechanical properties of waste tyre dust/carbon black hybrid filler filled natural rubber compound. Journal of Applied Polymer Science, 121, 1143-1150. Doi: 10.1002/app.33511

Job, A.E., Oliviera, F.A., Alves, N., Gacometti, J.A., \& Mattoso, L.H.C. (2003). Conductive composites of natural rubber and carbon black for pressure sensors. Synthetic Metal, 135-136, 99-100. Doi: 10.1016/S03796779(02)00866-4 
Konar, B.B., \& Saha, M. (2012). Infuence of polymer coated $\mathrm{CaCO}_{3}$ on vulcanization kinetic of natural rubber/sulfur/n-oxydiethyl benzthiazyl sulfenamide (BSM) system. Journal of Macromolecul Science Part A: Pure Applied Chemistry, $49(3), \quad 214-226$. D o i : $10.1080 / 10601325.2012 .649207$

Kselik, R.A.L., Smilde, K.W., Ritzema, H.P., Subagyono, K., Saragih, S., Damanik, M., \& Suwardjo, H. (1993). Integrated research on water management, soil fertility and cropping systems on acid sulphate soils in South Kalimantan, Indonesia. Proceeding of Ho Chi Minh City Symposium on acid sulphate soils (pp. 177-194). Ho Chi Minh City, Vietnam: IILRI Publication.

Lawandy, S.N., Botros, S.H. \& Mounir, A. (1993). Effect of vulcanizing agent concentration on the swelling behavior of chloroprene rubber under compression strain. Polymer-Plastics Technology and Engineering, 32(3), 223-235. Doi: 10.1080/03602559308 019229

Long, H. (1985). Basic compounding and processing of rubber. USA: Rubber Division, American Chemical Society.

Manoj, K.C., Kumari, P., \& Unnikrishnan, G. (2011). Cure characteristics, swelling behaviors, and mechanical properties of carbon black filler reinforced EPDM/NBR blend system. Journal of Applied Polymer Science, 120, 2654-2662. Doi: 10.1002/app.33476

Marković, G., Marinović-Cincović, M., Jovanović, V., Samaržija-Jovanović, S., \& Budinski-Simendić, J. (2013). NR/CSM/biogenic silica rubber blend composites. Composites Part B: Engineering, 55, 368-373. Doi: 10.1016/j.compositesb.2013.06.045

Mathew,S., Brahmakumar, M., \& Abraham, T.E. (2006). Microstructural imaging and characterization of the mechanical, chemical, thermal, and swelling properties of starch-chitosan blend films. Biopolymers, 82(2), 176-187. Doi: 10.1002/bip.20480
Nabil, H., Ismail H., \& Azura, A.R. (2013). Compounding, mechanical and morphological properties of carbonblack-fller natural rubber/recycled ethylene-propylene-diene-monomer blends. Polymer Testing, 32(2), 385-393. Doi: 10.1016/j.polymer testing.2012.11.003

Napitupulu, S.M., \& Mudiantoro, B. (2015). Pengelolaan sumber daya air pada lahan gambut yang berkelanjutan. Proccedings of $1^{\text {st }}$ Annual Civil Engineering Seminar 2015 (p. 330337). Pekanbaru, Indonesia: Universitas Riau.

Ramesan, M.T., Alex, R., \& Khanh, N.V. (2005). Studies on the cure and mechanical properties of blends of natural rubber with dichlorocarbene modified styrene-butadiene rubber and chloroprene rubber. Reactive \& Functional Polymers, 62, 41-50. Doi: $10.1016 /$ j.reactfunctpolym.2004.08.0 02.

Ritzema, H., Limin, S., Kusin, K., Jaunianen, J., \& Wösten, H. (2014). Canal blocking strategis for hydrological restoration of degrade tropical peatlands in Central Kalimantan, Indonesia. Catena, 114, 11-20 Doi: 10.1016/j.catena. 2013.10.009

Saad, I.S., Fayed, M.Sh., \& Abdel-Bary, E.M. (2009). Effects of carbon black content on cure characteristics, mechanical properties and swelling behaviour of 80/20 NBR/CIIR blend. Proceedings of 13th International Conference on Aerospace Sciences \& Aviation Technology, ASAT-13 (p.1-9). Kairo, Egypt: The Military Technical College Cairo. Diaksess dari http://www. mtc.edu.eg

Sulistiyanto,Y., Vasander, H., Jauhiainen, J., Rieley, J.O., \& Limin, S.H. (2008). Nutrient content of rainfall, water in canal and water at different depths in peatland in Central Kalimantan, Indonesia. In J.H.M. Wösten, J.O. Rieley \& S.E. Page (Ed.). Restoration of tropical peatlands. Wageningen, Netherland: Alterra - Wageningen University and Research Centre, and the EU INCO - RESTORPEAT Partnership. 
Widyanti, E. (2011). Kajian optimasi pengelolaan lahan gambut dan isu perubahan iklim. Tekno Hutan Tanaman, 4(2), 57 - 68

Van Duin, M., \& Dikland, H. (2007). A chemical modification approach for improving the oil resistance of ethyleneepropylene copolymer. Polymer Degradation and Stability, 92, 2287-2293. Doi: 10.1016/j.poly mdegradstab.2007.04.018
Vinson, J.R., \& Sierakowski, R.L. (1993). The behavior of structures composed of composite materials. Dordrecht, Netherlands: Kluwer Academic Publishers. 